\title{
Economic Pragmatism of Yogyakarta Muslim Community in Selecting Banking Institutions
}

\author{
Itsla Y. Aviva, Misnen Ardiansyah, Syafiq M. Hanafi \\ IAIN Palangka Raya, Indonesia \\ UIN Sunan Kalijaga, Yogyakarta, Indonesia \\ itslayunisvaaviva@gmail.com, misnen.ardy91@gmail.com, syafiqelan@yaboo.com
}

\begin{abstract}
.
This research discusses the motives of the Muslim community in choosing banking institutions by using the analysis of pragmatism theory. This research is qualitative research using a phenomenology approach. Data collection that is used in this research is the interview and observation. The result of the study indicated that the Muslim's customer of Yogyakarta tend to be pragmatic due to the character of society which has more accommodating and flexible philosophy of life (tolerance). This pragmatic attitude was influenced by the internal factors (cognitive limitations) and external factors (reputation and service of Conventional Banks). Furthermore, adopting from the theory of Schutz's motives that the motives reason (because of motive) of Yogyakarta's Moslem customers in choosing to the bank are their inconsistency in choosing is influenced by economic and service motives that are stronger than religious motives. As for their destination motive (in order to motive) namely fulfilling their needs.
\end{abstract}

Keyword: Because Motive, Customer Decision, Pragmatism, In Order to Motive.

Permalink/DOI: bttps://doi.org/10.18326/infsl3.v14i2. 201-220 


\section{Introduction}

Pragmatism is a model of interaction and response to external stimuli, related to the historical ethos of socialism, and the scourge of the free ownership system (Livingston, 1997: 279). There are two dominant meanings of pragmatism. First, look at cause and effect based on reality for practical purposes. Second, what is considered right is what is useful or functioning (Knight, 2008: 79). Pragmatism is a thought that has increasingly developed in the 20th century. The influence of pragmatism spread to various areas of life such as religion, education, socio-culture, ethics, law, politics, and economics. In the philosophical approach, pragmatism is a way of thinking that places the truth of an opinion measured by its practical results (outcome). Besides, pragmatism is often interpreted as an understanding that emphasizes more results than the theory that underlies that way of thinking (Wasitohadi, 2012: 176). The economic pragmatism in this paper is an opinion that stated to achieve the prosperity of the community, economic actions are considered more relevant than discussing the principle of reality (ontology).

The banking system in Indonesia is classified into two financial systems namely conventional and sharia. Conventional banking is banking that prioritizes the intermediation function based on the interest rate. Whereas, Islamic banking is banking that prioritizes financial management in its intermediation function which is based on the profit-sharing system. The difference in the banking system will contribute to differences in competitive strategies in the national and international financial industry. The banking strategy will be faced with fluctuating competition patterns, especially on differences in the interest rate system and profit sharing for managing banking products for the public. Competition in the conventional and sharia banking industry will be increasingly stringent in offering various products to the public.

The development of Islamic banking in Indonesia has entered the age of 28 years. Although it can be said to be late compared to other Muslim countries, its development is quite rapid (Karim, 2010: 25). Supported by the enactment of Law No. 21 of 2008 concerning Islamic banking issued on July 16, 2008, the development of the national Islamic banking industry increasingly has an adequate 
legal basis and encourages its growth even faster (Cahyani, 2016: 152). Statistical data of the Financial Services Authority (FSA) as of Mei 2020 has stated that recorded 196 Islamic banking industry players with details of 14 Sharia Commercial Banks (BUS), 20 Sharia Business Units (UUS), and 162 Sharia Rural Banks (BPRS). The office network owned by Islamic banks has penetrated the number of 2.957 offices, the number of ATMs is 3.012 with a total of 61.894 employees (Otoritas Jasa Keuangan, 2020: 4).

As the largest muslim population in the world, Islamic banking growth in Indonesia lower than conventional bank. Ideally the potential growth of Islamic banking in Indonesia is directly proportional to the population of Indonesia, which is predominantly Muslim. But in fact, the performance of the Islamic banking industry in Indonesia has not met public expectations. For three years in a row, the market share of Islamic banks in the country has been still less than 7 percent. This has been seen from the national market share of Islamic banking as of June 2020 which has been very small compared to conventional banking, which is only 6,18\% (Otoritas Jasa Keuangan, 2020: 2), as shown in the figure 1 below.

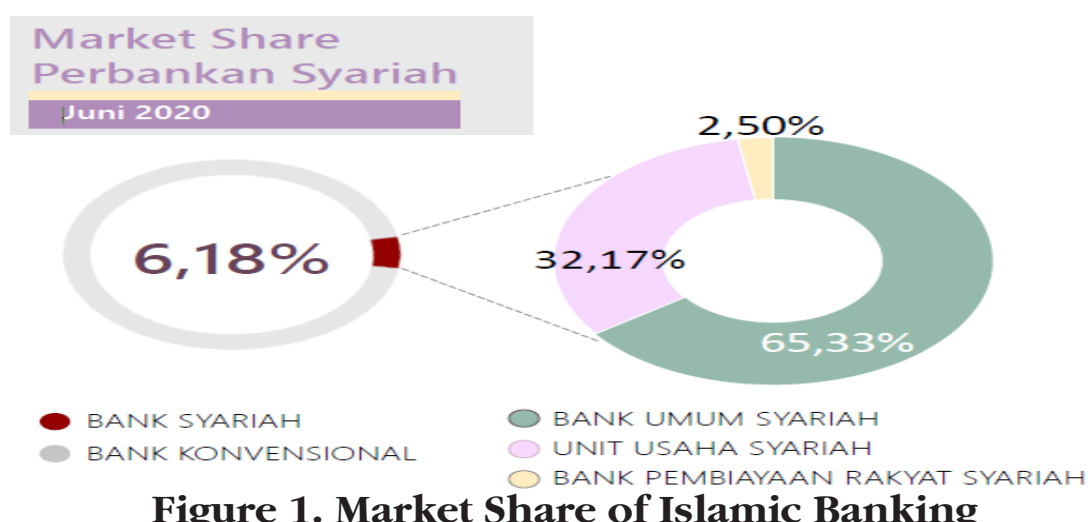

Source: Sharia Banking Snapshot June 2020

It referred to the MUI fatwa decision on Interest, the interest system imposed by conventional banks is prohibited in Islam and must be avoided by every Muslim because the interest system is included in usury due to the additional costs of funds borrowed 
by customers. But in reality, the growth of Islamic finance, especially Islamic banking has not been able to offset the growth of conventional finance. This condition also occurs in the Special Region of Yogyakarta (DIY) with the magnitude of Islamic banking assets as of May 2019 at 9.5\% of the total banking assets in DIY (Bank Indonesia, 2019: 60). Although this has been the highest in the history of the existence of Islamic banks in DIY and exceeded the national level market share. This condition reflects the unpreparedness of the community in the process of receiving the Islamic banking system and Islamic banks have not proven themselves useful in practical, effective, efficient, and beneficial.

Human attitude tends to lead to something practical, which must be accepted easily. something is done easily and solve problems with results that are considered successful by satisfying showing that pragmatism has become the mindset of some humans. without exception in banking institutions, each customer will have tried to maximize the use-value in choosing a banking institution to save funds, conduct credit or financing or services. therefore, it appears that pragmatism also colors the economic behavior of customers in choosing a bank. Departing from the above phenomenon, the writer is interested to study it in an article about Economic Pragmatism of Yogyakarta Muslim Community in Selecting Banking Institutions. With the formulation of the problem which is why Muslim customers in the city of Yogyakarta tend to be pragmatic in choosing a banking institution? And what are the motives of Yogyakarta's Muslim customers in choosing banking institutions?

\section{Literature Review}

\section{Economic Pragmatism}

Pragmatism is etymologically derived from Greek, which is from the word pragma which means action. Pragmatism means philosophy or understanding of action (Keraf, 1987: 15). Everything is valued as far as it can be done in action. The birth of pragmatism was stimulated in part by Darwin's theory of evolution. Darwin's Theory of Evolution shifts the focus from being to becoming and subverts belief in the main doctrines of the origin of life. This shift in attention to becoming has caused people to prioritize themselves to talk about methods rather than to be preoccupied with issues about 
the nature of things. The question "How does something happen?" becomes more important than the question "What is something?" (Keraf, 1987: 19).

Pragmatism is better known as one of philosophical thinking flow which is often associated as a "typical American" way of thinking which was born around the 1870 s which has three phases in its growth, namely the initial phase - Charles S. Pierce (18391914), William James (1842-1909) and John Dewey (1859-1952) (Syafi'i, 2012: 23). Pierce has taught that human knowledge is true, not because it reflects or creates reality, but if it can prove its benefits to the public. So the value of that knowledge depends on its real application in society. As for Dewey, what is important is not right or wrong of knowledge, but the extent to which humans can solve problems that arise in life. The measurement of truth is public, while human reason and thinking are only a means (Mudhofir, 1996: 75-76). According to Dewey, pragmatic means the rules of reflective thinking which are the main focus and finally the result (Russell, 2007: 240). Meanwhile, James teaches that the measure of the truth of something is determined by its practical consequences. Knowledge is never true, but can only "be true". According to James, the measurement of truth should primarily be sought in the degree to which humans as individuals and psychics are satisfied. Absolute truth does not exist, because reality and human are constantly changing (Mudhofir, 1996: 75).

Pragmatic understanding is about developments that have experienced a shift in meaning. There is a shift in enthusiasm from the desire to "clear ideas with action" to the spirit "everything matters as long as practical use is achieved". The notion of Pragmatism which is often associated with practical use occurs because of the widely popular assumptions about pragmatism and the influence of the thought of neo-pragmatic figures (Mullin, 2007: xii). Distinctive characteristics of pragmatism that is the ability to be applied in practice or work most effectively. This principle then determines the truth of a statement, action, and judgment (Honderich, 2005: 709). Pragmatism in general opinion is often seen as a culture that prefers to be practical, instant, dislike the process, or only solves short-term problems. With a broad understanding of pragmatism, it 
is very dangerous for the community because of the narrow view that values everything from use value (Trinarso et al., 2015: 6).

Rasyid \& Ismail (2020) has analyzed the philosophical principles of Islamic banking, whether to maintain the ideal concept in the form of doctrine, or should it be changed with a more pragmatic approach. In practice, the ideal concept has not been implemented optimally. Sharia banks seem to have drifted along with a focus on seeking profit by ignoring the underlying philosophies. This can be seen from the various products offered dominated by Murabaha products. Whereas theoretically, Islamic banks do not aim for profit but have other responsibilities greater than that, namely how their existence can contribute positively to the welfare and justice of people's lives.

Yasin (2017) has mentioned that the rise of economic pragmatism in various countries has led to the acceleration of the same pragmatism in Indonesia and has unexpected implications for the dynamics of Islamic finance in Indonesia. In Indonesia, the pragmatic perspective is what has been seen as correct and useful or functioning. this not only affects individual personal but also institutional-collegial. As a financial intermediary institution engaged in the social-oriented and profit- oriented sector, Islamic banking in Indonesia is not sterile from a pragmatic perspective.

Witjaksono (2016) has stated that humans are homo economicus or economic man. it means that individuals are independent, autonomous, and rational, who pursue maximum satisfaction with minimum costs. For this reason, humans as consumers always assume to maximize the utility or benefit (utility maximization assumption) of each consumption. In other words measuring the merits of something seen from the aspect of the greatest benefit or usefulness for someone.

Motive Theory

The word "motive" is interpreted as an effort to encourage someone to do something. The motive can be said as a driving force from within and within the subject to carry out certain activities to achieve a goal (Sardiman, 2018: 73). Thus, motive is all force that drives someone to do something or act. 
In psychology, motives are power while motivation is a process, motives are needs while motivation is a desire. Both are different but influence each other. According to Alex Sobur, motivation means arousing motives, arousing movement, or moving a person/self to do something to achieve satisfaction or goal (Sobur, 2003: 268). Numerous studies have shown that consumer purchasing decisions are the result of encouraging needs or motivation. Among them are Hou (2013) and (Darley, Blankson, \& Luethge, 2010) who have stated that motivation takes many forms, and has also been proven to influence consumer purchasing decisions how they choose how to meet their needs. Motivation is born because of a motive.

Adopting the opinion of Alfred Schutz to understand the motives and meaning of individual actions, it is important to note not only the motive of the goal in order to motive but also the motive of the reason (because of motives) that underlie it before reaching the goal motive. The goal motives are future-oriented and are described as; intentions, goals, hopes, interests, and so on, while the motives of reason are oriented to the past (Farid, 2018: 120). In his book entitled The Phenomenology of Social World, it turns out that Schutz distinguishes between actions and behavior. For him, the action is an execution of a projected act (a projected act). While behavior is considered as an activity where the ego does not reflect, which must be distinguished from the action (Supraja, 2012: 88). So the meaning of action is always associated with a projected action.

The actions of Muslim customers in selecting banking institutions are subjective actions based on certain motives. Motives arise because of needs. Needs can be seen as lacking something and this demands immediate fulfillment, to get balance. In economics, this deficiency or scarcity is known as scarcity which has two meanings, namely: first, it is limited in the sense that it is not enough compared to the many human needs. Second, it is limited in the sense that humans must make sacrifices to get it. The point is that a person must have unlimited needs or desires while the need for resources is limited, causing each person to have to choose between the options to achieve maximum satisfaction. This shortage situation in this paper is one of the motive reasons (because motive) for customers to use the services of banking institutions. 
Daniar (2012) has explained the decision to choose a bank is influenced by many factors, not only in pragmatic tendencies but can also be influenced by families, reference groups, and the quality of the products offered. The results of his research have stated that the motives of Muslim customers to choose conventional bank products are intended to support their goal of obtaining material needs (vehicles, houses) and ease of transactions with third parties, for various reasons. Some informants have been forced to choose conventional banks to meet their needs that only exist in conventional banks, but the compulsion has been based on the perception of conventional bank values that are subjective, namely the perception of bank interest is the same as usury, in other words when the perception of value changes, then "compulsion" will also experience changes.

Rivai et al. (2007) have stated that although various noneconomic factors are very influential on people's interactions with the banking world, in the decision to choose banking services, rational choice is still crucial. In his research, it has also been mentioned how important it is to prioritize the quality of service and other benefits offered rather than just by making an emotional approach.

\section{Decision-Making Factors}

The decision is a process of problem-solving approach that consists of the introduction of problems, finding information, some alternative assessments, making buying decisions, and behavior after buying through which consumers pass (Kotler \& Keller, 2009: 234). In general, the process of making economic decisions of every consumer is through the process of thinking, acting, and acting rationally. a decision based on his theory is an analytic approach to choose the best alternative or the best way to act.

A customer's decision is part of one of the important elements of customer behavior, in addition to physical activities that involve customers in assessing, obtaining, and using economic goods and services. The problem-solving perspective covers all types of behaviors that fulfill needs and a broad range of factors that motivate and influence customer decisions (Sufitrayati \& Nailufar, 2018: 6). Before determining the choice of the bank to be used, generally, the 
customer will evaluate to make a selection of products or services offered by banks, both conventional banks, and Islamic banks. The evaluation and selection used will produce a decision.

The research related to factors that influence decisions in choosing a banking system was conducted by Mariyono (2013) which explains that age, gender, and religion encourage customers to choose Islamic banks as a place to save. On the other hand, the level of income, employment, and education level encourage customers to prefer conventional banks. Furthermore, in the research of Sari et al. (2015), it is shown that the factors that influence people to become customers of Islamic banks are influenced by psychological, personal, socio-economic, and cultural factors.

\section{Islamic Banking: Reality and Hope}

Fasa (2013) has mentioned that there are at least several things that have caused the Islamic banks to slow down in increasing market share. First, the rationality of Muslims in economics, in which the pursuit of materials benefits does not take into account the halal issue of the prohibition of bank interest which according to the MUI fatwa decision is equated with usury. Secondly, people's understanding of Islamic banks is still very low. Third, there is no unanimous support from religious institutions such as Nahdlatul Ulama and Muhammadiyah regarding the prohibition of interest as usury. Fourth, Islamic banks in Indonesia, face challenges where banks operate in a mixed economic system that is less supported by regulations because supervision is still integrated with conventional banks. So that the Islamic banking development strategy is needed in the face of conventional banking competition.

Understanding and socialization of the public about Islamic banking products and systems in Indonesia are still very limited. Even though the majority of Indonesia's population are Muslims, the development of sharia products is still slow. Efforts to develop Islamic banks are not enough to only be based on legal aspects and regulations, but also must be oriented to the market or the community as users of services (consumers) of banking institutions. Customer behavior towards banking products can be influenced by people's attitudes and perceptions of the characteristics of the banking sector 
itself. The structure and perception of the community towards Islamic banks largely determine the behavior of the community.

Nevita \& Arifin (2015) have stated that religious factors or perceptions that are only based on religious reasons do not necessarily affect people's behavior towards decisions in using a type of banking service. This also agrees with the research conducted by Dawami (2020), Butt et al. (2018), Lajuni et al. (2017), Bodibe et al. (2016), Ali et al. (2015), Pepinsky (2010) and Adawiyah (2010) stated that religion is not the main factor to attract consumers using Islamic banks, but there are other important factors in marketing Islamic banking. And the interesting thing is consumers have done something they liked rather than did something because of the need for obligations.

The hesitation of the Muslim community to believe in Islamic banks caused them to choose the attitude of "ambiguity" (agreed with the MUI fatwa No.1 of 2004 concerning Interest (Interest/ Fa'idah) but in practice, they still use conventional bank accounts). Evidenced by the results of research Mochlasin (2017) which has mentioned that the variable knowledge of the fatwa forbidden bank interest did not have a significant positive effect on the desire to use Islamic banks.

Besides, the results of research by Cahyani et al. (2013) showed that the bank interest perception factor on saving interest in BNI Syariah Bank in Semarang was only around $13.2 \%$ and $86.8 \%$ explained by other factors. This has become a common understanding for the Muslim community that the prohibition of the fatwa on bank interest does not apply binding on every Muslim and is merely a recommendation not as a necessity. Furthermore, it has been mentioned in the research of Aisyah (2018) and Iswana (2016) that customers are still not quite satisfied with Islamic banking services and still doubts the professionalism of Islamic banking. Thus, theoretically Islamic banking has provided benefits to the community. But in reality, many Sharia Bank products are unable to accommodate the needs of the community and the service process is more complicated and appears to be difficult for customers. 


\section{Methods}

This research was a type of qualitative research. This research used descriptive-qualitative paradigm method because it was to understand the phenomenon as a whole. While the approach used in this research was the phenomenology approach. With this phenomenological approach, the researcher sought to understand and uncover phenomena that emerge. The data collected can be either primary data or secondary data. The primary data in this study were the results of interviews with 9 (nine) customers of the city of Yogyakarta who have a) conventional bank accounts, b) conventional bank accounts \& Islamic bank accounts, with their religious background being Islam. While secondary data in this study were obtained from literature, journals, documents, or other data related to research. Data collection techniques in this study were: (1) interviews; (2) observation; and (3) documentation.

Data processing was done qualitatively by relying on analysis and interpretation to then be described using certain perspectives or theoretical frameworks. Assuming "the economic pragmatism of Muslim customers in the decision to choose a bank" as an initial hypothesis, the intended data processing will be carried out with economic pragmatic as a theoretical framework approach.

\section{Results and Discussion}

Pragmatic Economics of Muslim Clients

The results of the interview stated that there are still many people in Yogyakarta who become conventional bank customers even though some of them also have Islamic bank accounts. For customers who have two accounts (conventional banks and Islamic banks), it turns out that at the practical level they more often use conventional bank accounts in their financial transactions due to several things. First, the ability of conventional banks to work more effectively in accommodating community needs. It is emphasized by SS and RN statements that the products offered are more varied so that they can meet customer needs. Besides, the presence of conventional banks which predate Islamic banks has made the reputation of conventional banks better and their capital conditions stronger.

Second, IT in conventional banks is better than Islamic banks. 
This is supported by the CS argument that access to conventional bank ATMs (automatic teller machines) is easier to find and the internet network is more stable. Third, the application of quality service (service excellence) at conventional banks, namely fast and hassle-free service, especially in terms of credit. It is strengthened by EF's opinion that the process of applying for loans from conventional banks is easier than Islamic banks, especially in terms of efficiency in submitting and disbursing funds.

Fourth, the level of profit offered by conventional banks is higher than Islamic banks. As explained by TH that the extent to which banks can offer a lower rate of return for loans and a higher rate of return for deposits, that is what tends to influence customers in choosing a bank. This can happen because customers think more rationally and emotionally in economics, where the pursuit of material gain does not really consider the halal issue of the haram of bank interest. It is strengthened by the ED's recognition which states that some Islamic banks not only determine a predetermined ratio, but the value can even be higher than the conventional loan interest. This happened after various fees and additional fees. So that according to him, applying for credit at a conventional bank is more profitable for customers.

Based on the above statement, it is clear that these four things are a distinctive characteristic of pragmatism that is the ability to be applied in practice or work most effectively. This principle then determines the truth of a statement, action, and judgment (Honderich, 2005: 709). Facts on the ground show that only borrowing customers (debtor customers) tend to be pragmatic in choosing a bank. They prioritize practicality in terms of usefulness or benefit. This pattern of pragmatism arose when conventional banks were able to provide speedy service for disbursing funds so that customers can immediately use it to fulfill their needs. This can be a reference for improvements in Islamic banking to be more practical and beneficial to the community. Especially in the case of loans.

Furthermore, the observations of researcher that the majority of the people of Yogyakarta are familiar with the existence of Islamic 
banks. Interestingly, most of them already know the principles of Islamic banking. However, this does not make them choose or use Islamic banks. Thus, the Muslim community's lack of interest in Islamic banking is not due to limited information but rather a lack of attention to this information which is interpreted as a cognitive limitation. The cognitive ability in question is attention and understanding of the knowledge of religion, especially in Islamic transactions. This can be seen from the behavior of the community in the decision to use banking services that religious reasons do not necessarily influence their choice. They are more oriented towards results and goal achievement. As long as conventional banks are able to provide solutions to their needs, then for them, it is not a problem.

Thus, the greater the use-value and benefits, the greater the degree of validity. Likewise, the decision of Yogyakarta Muslim customers who tend to be pragmatic in selecting a bank, is which bank they consider appropriate and feasible, measured by price, convenience, profit, and reliability of the products they get. This has been motivated by the character of the people who are more accommodating and their philosophy of life is flexible (tolerance) so that even in the economy also tolerance. This pragmatic attitude is influenced by internal factors (lack of literacy on the background of lack of attention to information that is interpreted as limited cognition) and external factors (reputation, credibility, and services of Conventional Banks). A simple pragmatic measure which according to them is rational is seen in terms of profit, usefulness, and practicability.

\section{Customer Motives in Selecting a Bank}

Based on the results of interviews, they become bank customers who are driven by motives to meet their needs, including the need to save and borrow money. This is consistent with HR's statement that the motive for the need to save money in a bank is due to be on guard in transactions and investments. Therefore, to meet these motives, the bank offers the appropriate product namely; Savings that can be designated to meet the needs of the guard, Giro to meet the needs of transactions and deposits (time savings) to meet 
the needs of investment. Among the three savings products, the majority of them have savings products that are used to facilitate transactions with third parties such as payment of salaries, payment for purchases of goods, and precautionary needs (KR). Meanwhile, loan products that are widely used are in the form of consumer loans, especially Motorized Vehicle Loans (KKB) and Home Ownership Loans (KPR) although some apply for productive loans, namely for business development.

Based on the observations of researchers, for customers who have two bank accounts (Islamic banks and conventional banks), conventional banks are considered as surrogate or temporary goals because the main objectives are difficult to obtain. Indeed, they want products that come from Islamic banks, but for reasons of dependence with third parties or Islamic bank, products are still not following their needs. the customer finally chooses a conventional bank as a substitute destination (MZ and RH). This inconsistency can also be due to economic and service motives being stronger than religious motives. This has become an evaluation for Islamic banks to be more practical and useful for the community with innovative product development and services that are competitive and based on community needs. The development of Islamic financial products should not just imitate conventional financial products. Islamic financial institutions must create unique products and services that can meet the real needs of the community. This is because most Muslim communities in Indonesia prioritize aspects of service and convenience compared to the aspects of sharia. And what's interesting is that they do something they like, not do something out of necessity.

The reality of customer choice has led to two concepts namely because of motive (motive of reason) and in order to motive (motive of purpose) in its actions. Thus, it can be concluded that the main problem explained by Schutz stated that the motive is a context of meaning that connects motivation with what is motivated. The motive of a person to be a banking customer to fulfill their needs both consumptive or productive. In nature is what is called an in order to motive because it is oriented towards the future such as owning a vehicle, home, or business development. The reasons 
for economic pragmatism as mentioned earlier such as ease of getting services, ease of location, or because they already have an account at a conventional bank related to salary payments, can be categorized as motive reasons (because of motive) because this is the customer's starting point for selecting a particular bank to get the next destination. This motive is the reason that serves as a force or impetus that causes a person to act (become a conventional bank customer) to meet the needs for achieving a balance which is also called the goal motive (in order to motive).

\section{Conclusion}

Based on the results of interviews and observations, bank muslim customers in Yogyakarta tend to be pragmatic in selecting a bank, meaning which bank they consider appropriate and feasible, is measured based on price, convenience, profit, and reliability of the products they get. Their pragmatic attitude is also motivated by their accommodative characters and tolerance philosophy when it comes to economic activities. This attitude is influenced by internal factors (lack of literacy due to lack of attention on information that is interpreted as cognitive limitation) and external factors (reputation, credibility, and services of Conventional Banks).

Adopting the theory of Alfred Schutz's motives, there are two motives of bank Muslim customers in Yogyakarta selecting the bank, first because motives (reason motives) it is their inconsistency in choosing the dominant which is pragmatic. This inconsistency is caused by economic and service motives that are firmer than religious motives. Second, in order to motive (goal motive), it is the motives of Yogyakarta bank Muslim customers that are the fulfillment of their needs.

From this research, it is suggested the need for rethinking the concept of Sharia Bank system, in terms of improving Human Resources and designing full-fledged standards in the application of sharia products and their provisions, to avoid deviant potential from what have been set and implemented sharia. As it is expected to create a competitive and efficient Sharia Bank system (able to compete globally) and to be beneficial for the people (to satisfy the public's necessity of sharia banking services that are kaffah in Indonesia as well as to increase the proportion of profit-sharing financing). 


\section{References}

Adawiyah, W. R. (2010). Pertimbangan, Pengetahuan, dan Sikap Konsumen Individu Terhadap Bank Syariah. Jurnal Ekonomi Pembangunan, 11(2), 191-201. https://doi.org/10.23917/jep. v11i2.324

Aisyah, M. (2018). Islamic Bank Service Quality. Al-Iqtishad: Jurnal Ilmu Ekonomi Syariah (Journal of Islamic Economics), 10(2), 367-388.

Ali, M., Raza, S. A., \& Puah, C.-H. (2015). Factors affecting intention to use Islamic personal financing in Pakistan : Evidence from the modified TRA model . Munich Personal RePEc Archive, (66023), 1-27.

Bank Indonesia. (2019). Laporan Perekonomian Provinsi Daerah Istimewa Yogyakarta: Permintaan Domestik Menguat, Pertumbuhan Ekonomi DIY Melesat. Yogyakarta.

Bodibe, S., Chiliya, N., \& Tarisayi, C. (2016). The factors affecting customers' decisions to adopt Islamic banking. Banks and Bank Systems, 11(4), 144-151.

Butt, I., Ahmad, N., \& Ahmed, Z. (2018). Determinants of low adoption of Islamic banking in Pakistan, 9(3), 655-672. https:// doi.org/10.1108/JIMA-01-2017-0002

Cahyani, A., Saryadi, S., \& Nurseto, S. (2013). Pengaruh Persepsi Bunga Bank Dan Kualitas Pelayanan Terhadap Minat Menabung Pada Bank Bni Syariah Di Kota Semarang. Jurnal Ilmu Administrasi Bisnis S1 Undip, 2(3), 371-379.

Cahyani, P. D. (2016). Tingkat Kepuasan Nasabah Terhadap Kualitas Layanan Perbankan Syariah di Yogyakarta. ESENSI: Jurnal Bisnis Dan ManajemenBisnis Dan Manajemen, 6(2), 151-162. https://doi.org/10.15408/ess.v6i2.3570

Daniar, A. (2012). Persepsi dan Motif Menjadi Nasabah Bank Konvesional Bagi Nasabah Muslim. Motif, 1-14.

Darley, W. K., Blankson, C., \& Luethge, D. J. (2010). Toward an integrated framework for online consumer behavior and decision making process: A review. Psychology and Marketing, 
27(2), 94-116. https://doi.org/10.1002/mar.20322

Dawami, Q. (2020). Factors Influencing The Preference Of Customers Towards Islamic Banking : Evidence From Malaysia. Journal of Islamic Economic Laws, 3(1), 48-67.

Farid, M. (2018). Fenomenologi: Dalam Penelitian Ilmu Sosial. PrenadaMediaGroup.

Fasa, M. I. (2013). Tantangan Dan Strategi Perkembangan Perbankan Syariah Di Indonesia. Jurnal EKONOMI ISLAM, 2(1), 19-40.

Honderich, T. (2005). The Oxford companion to philosophy. (T. Honderich, Ed.) (2nd ed.). Oxford University Press. https:// doi.org/10.5860/choice.33-2495

Hou, C.-I. (2013). Study On Decision-Making for Cafe Management Alternatives. International Journal of Computer Science and Information Technology, 5(6), 67-75. https://doi.org/10.5121/ ijcsit.2013.5605

Iswana, Z. (2016). Bank Syariah Antara Realita dan Harapan Masyarakat Muslim. Hukum Islam, 16(2), 170-181. https://doi. org/10.24014/hi.v16i2.2678

Karim, A. A. (2010). BANK ISLAM : Analisis Fiqih dan Keuangan (Ke-4). Jakarta: PT RajaGrafindo Persada.

Keraf, S. (1987). Pragmatisme menurut William James (1st ed.). Yogyakarta: Kanisius.

Knight, G. R. (2008). Issues and Alternatives in Educational Philosophy (4th ed.). Andrews University Press.

Kotler, P., \& Keller, K. L. (2009). Manajemen pemasaran Jilid 1. Jakarta: Erlangga.

Lajuni, N., Wong, W., Ming, P., Yacob, Y., Ting, H., \& Jausin, A. (2017). International Journal of Economics and Financial Issues Intention to Use Islamic Banking Products and Its Determinants. International Journal of Economics and Financial Issues, 7(1), 329-333.

Livingston,J.(1997). Pragmatismand the PoliticalEconomyofCultural 
Revolution, 1850-1940. The Journal of American History. Univ of North Carolina Press. https://doi.org/10.2307/2945534

Mariyono, J. (2013). Determinants of Customers in Selecting Sharia Banking System for Saving in East Java - Indonesia. Journal of Economics, Business, and Accountancy I Ventura, 16(3), 457-472. https://doi.org/10.14414/jebav.v16i3.225

Mochlasin. (2017). Peran Fatwa Haram Bunga Bank Terhadap Faktor-faktor Yang Mempengarubi Perilaku Nasabah Muslim Bank Syariah. UIN Sunan Kalijaga.

Mudhofir, A. (1996). Kamus Teori dan Aliran Dalam Filsafat.

Mullin, R. (2007). The Soul of Classical American Philosophy: The Ethical and Spiritual Insights of William James, Josiah Royce, and Charles Sanders Pierce. State University of New York Press.

Nevita, A. P., \& Arifin, Z. (2015). Perilaku, Karakteristik, Persepsi Masyarakat Terhadap Bank Syariah Di Eks Karisidenan Kediri. Nusantara of Research Universitas Nusantara PGRI Kediri, 02(2), 148-156.

Otoritas Jasa Keuangan. (2020a). Snapshot Perbankan Syariah Per Juni 2020. Snapshot Perbankan Syariah.

Otoritas Jasa Keuangan. (2020b). Statistik Perbankan Syariah per Mei 2020. https://doi.org/Diunduh pada tanggal 28 Juli 2020

Pepinsky, T. B. (2010). The Demand for Islamic Banking: Piety, Class, and Global Identity. International Political Economy Society, 1-39.

Rasyid, A., \& Ismail, N. (2020). Filosofi Perbankan Syariah: Antara Idealisme dan Pragmatisme. TAZKIA: Islamic Finance \& Business Review, 14(1), 51-64.

Rivai, H. A., Lukviarman, N., Syafrizal, Lukman, S., Andrianus, F., \& Masrizal. (2007). Identifikasi Faktor Penentu Keputusan Konsumen Dalam Memilih Jasa Perbankan: Bank Syariah vs Bank konvensional. Center for Banking Research Andalas University. https://doi.org/10.1177/0194599815597200 
Russell, B. (2007). Professor Dewey's "Essays in Experimental Logic" (1919). In D. M. Hester \& R. B. Talisse (Eds.), Essays in Experimental Logic: John Dewey (p. 303). Carbondale: Southern Illinois University Press (SIU Press). https://doi. org/10.2307/2940040

Sardiman. (2018). Interaksi dan Motivasi Belajar Mengajar. Jakarta: Rajagrafindo Persada (Rajawali Pers).

Sari, I. M., Wibowo, H., \& Suprapto, E. (2015). Factors that Influenced People to Become Islamic Bank Customer: A Study on Kancana VIllagers. Al-Iqtishad: Journal of Islamic Economics, 7(1), 7386. https://doi.org/10.15408/ijies.v7i1.1360

Sobur, A. (2003). Psikologi Umum. Bandung: Pustaka Setia.

Sufitrayati, \& Nailufar, F. (2018). Faktor-Faktor Yang Mempengaruhi Keputusan Nasabah Dalam Memilih Bank Syariah Di Kota Banda Aceh. Ibtiyath, 2(1), 1-22.

Supraja, M. (2012). Alfred Schutz: Rekonstruksi Teori Tindakan Max Weber. Jurnal Pemikiran Sosiologi, 1(2), 81-90. https:// doi.org/10.22146/jps.v1i2.23447

Syafi'i, I. (2012). The Progress of Science (Kajian Filsafat Pragmatisme Charles S. Pierce). In M. A. Mu'ammar \& A. W. Hasan (Eds.), Studi Islam : Perspektif Insider/Outsider (p. 554). Yogyakarta: IRCiSoD.

Trinarso, A. P., Ryadi, A., Widyawan, A., Adinda, A. J., \& Aribowo. (2015). Meninjau Ulang dan Menyikapi Pragmatisme Dewasa Ini Penulis. (A. J. Adinda \& E. Prasetyono, Eds.). Surabaya: Fakultas Filsafat Universitas Katolik Widya Mandala Surabaya.

Wasitohadi, W. (2012). Pragmatisme, Humanisme dan Implikasinya Bagi Dunia Pendidikan di Indonesia. Satya Widya, 28(2), 175190. https://doi.org/10.24246/j.sw.2012.v28.i2.p175-190

Witjaksono, M. (2016). Analisis Kritis dan Pragmatis Caring Economics sebagai Paradigma baru Kajian Ekonomi. Jurnal Ekonomi Dan Ekonomi Studi Pembangunan, 8(2), 217-244. https://doi.org/10.17977/um002v8i22016p217 
Yasin, M. N. (2017). Pragmatisme Perbankan Syariah dalam Penyelesaian Eksekusi Objek Hak Tanggungan Studi Putusan Nomor 116/Pdt.Plw/2015/PN.Kpn. Al-Ihkam: Jurnal Hukum E Pranata Sosial, 12(1), 42-66. https://doi.org/10.19105/alihkam.v12i1.1144 